DOI.

https://doi.org/10.22219/fths.v3i1

Received: Desember 2019

Accepted: Januari 2020

Available online: Februari 2020

\title{
Kajian Karakteristik Fisik dan Mekanik Edible Film Berbasis Pati Umbi Suweg (Amorphophallus paeoniifolius) dengan Variasi Konsentrasi Lilin Lebah
}

\author{
Evi Lusiana Dwi Safitri ${ }^{1}$, Warkoyo ${ }^{1^{*}}$, Rista Anggriani ${ }^{1}$ \\ ${ }^{1}$ Program Studi Teknologi Pangan, Fakultas Pertanian Peternakan, Universitas \\ MuhammadiyahMalang, Malang, Indonesia \\ *Corresponding author email:warkoyo@umm.ac.id
}

\begin{abstract}
Suweg tuber contains very high starch so that it can be used as one of the ingredients for edible film. The use of a single ingredient from the starch group has a disadvantage because it has a weak and rigid, so it needs to be added ingredients to improve the nature of edible film, namely by adding beeswax. The addition of beeswax is expected to improve the physical and mechanical properties of edible film because its hydrophobic nature is a barrier to the loss of steam from products packed by edible film. This research used a factorial randomized block design using two factors: suweg tuber starch concentration (3\%.4\%, and 5\%) and beewax concentration (1\%.2\%, and $3 \%)$. Parameters of research included analysis of raw materials in the form of water content, starch content and amylose starch content of suweg tubers whileanalysis edible film included thickness, transparency, tensile strength, elongation, solubility, water vapor transmission rate and surface structure. The results showed that there was a very real interaction between the addition of suweg tuber and beeswax starch to thickness, elongation, tensile strength, and water vapor transmission rate and there was a real interaction with the transparency and solubility of edible film. The best treatment with near-standard results is edible film with suweg tuber starch concentration $3 \%(b / v)$ and beeswax concentration $1 \%(b / v)$ The surface structure of edible film on starch addition $3 \%$ $(b / v)$ results in a structure that more flat and soft, while the addition of beeswax $1 \%(b / v)$ results in smaller pores.
\end{abstract}

Keywords: beeswax, edible film, suweg

\section{PENDAHULUAN}

Umbi suweg merupakan salah satu jenis umbi yang terdapat di Indonesia dengan jumlah yang tidak terlalu banyak dan cukup sulit untuk ditemukan dipasaran karena musiman. Meskipun jumlahnya yang sedikit, tanaman ini sebenarnya memiliki nilai ekonomi yang tinggi dan manfaat yang besar sebagai bahan pangan. Selain itu, umbi suweg dapat berpotensi sebagai pangan alternatif karena mengandung kadar pati yang cukup tinggi yaitu sekitar 8085\% dengan kadar amilosa sebesar 24,5\% dan kadar amilopektin sebesar 75,5\%. Syarat bahan dapat digunakan sebagai bahan baku pembuatan edible film 
adalah mempunyai kandungan pati yang cukup tinggi, oleh karena itu umbi suweg dapat digunakan sebagai bahan edible film. Menurut Penelitian Saputra dkk. (2015) edible film dari pati umbi suweg dengan penambahan gliserol pada konsentrasi yang berbeda menghasilkan kuat tarik dan elongasi yang semakin meningkat, dan akan mengalami penurunan ketika gliserol yang ditambahkan semakin banyak dikarenakan penambahan gliserol yang semakin banyak menyebabkan edible film menjadi lebih lentur dan mudahsobek. Berdasarkan hasil penelitian tersebut perlu adanya modifikasi dengan penambahan bahan lain untuk meningkatkan karakteristik fisik dan mekanik edible film dari pati umbi suweg.

Penggunaan bahan tunggal pada edible film seperti pati masih menyisakan beberapa kekurangan diantaranya adalah sifat rapuh dan kaku. Edible film yang terbuat dari polisakarida juga mempunyai sifat penghambatan yang baik terhadap gas daripada uap air. Permeabilitas film ini dipengaruhi oleh sifat kimia bahan, struktur polimer, kondisi uji, dan sifat bahan yang akan berdifusi. Hal ini diperlukan penambahan suatu bahan untuk memperbaiki sifat dari polisakarida salah satunya dengan penambahan lilin lebah. Adanya penambahan lilin lebah diharapkan mampu memperbaiki sifat mekanik film yang dihasilkan dengan meningkatkan ketebalan film karena terbentuknya kristal lilin lebah pada matriks film. Menurut penelitian Dhimas dkk. (2018) penambahan lilin lebah pada edible film dengan konsentrasi yang $1 \%-3 \%$ dapat meningkatkan nilai ketebalan karena terbentuknya matriks film dan menghambat laju transmisi uap air lebih baik karena sifat lilin yang hidrofobik. Penambahan lilin lebah pada konsentrasi 4\% - 5\% dapat menurunkan karakteristik edible film karena lilin lebah melampui titik jenuhnya sehingga tidak homogen dalam campuran bahan edible film sehingga perlu dilakukannya penelitian lebih lanjut untuk mengetahui konsentrasi yang tepat untuk mempertahankan karakteristik edible film tersebut.

Edible film dari komposit yang terdiri dari hidrokoloid dan lipid memungkinkan terjadinya perbedaan kepolaran sehingga diperlukan penambahan emulsifier, yaitu STTP (Sodium Tripolyphospate). Penambahan STTP ini diharapkan dapat menyatukan kepolaran larutan edible film yang berbeda. Pada dasarnya penggunaan edible film tergantung dari karakteristik produk yang akan dikemas. Kajian karakteristik edible film pati suweg ini dapat menentukan sifat fisik dan mekanik edible film yang dijadikan acuan dalam penyesuaiannya dengan produk yang akan dikemas. 


\section{METODE PENELITIAN}

\section{Bahan}

Bahan utama dalam penelitian ini adalah umbi suweg dengan tingkat kematangan sedang dengan warna umbi suweg dominan coklat, ukuran yang tidak seragam dan umurnya masih muda karena dipanen pada awal musim serta diperolah dari Magetan, Jawa Timur.

Alat

Alat yang digunakan pada penelitian ini yaitu timbangan analitik Pioner Ohaus, gelas water vapor transmission rate/WVTR, oven, alat pengukur tekstur EZ-SX Texture analyzer (Shimadzu), Spectrophotometer UV-Vis (Shimadzu), SEM (Scanning Electron Microscopy) Tabletop Hitachi TM-3000.

\section{Proses Pembuatan Pati Umbi Suweg}

Umbi suweg dikupas, kemudian direndam dengan larutan $\mathrm{NaCl}$ 10\% selama 24 jam untuk menghilangkan kalsium oksalat. Setelah 24 jam umbi suweg dicuci dengan air mengalir untuk menghilangkan sisa kotoran yang masih menempel pada umbi. Kemudian umbi suweg diparut, lalu dilakukan ekstraksi pati dengan penambahan air. Hasil ekstraksi kemudian diendapkan selama 12 jam. Endapan yang diperoleh dikeringkan menggunakan cabinet dryer pada suhu 50 o C selama 6 jam, kemudian padatan kering selanjutnya dihaluskan dan diayak. Padatan yang lolos 80 mesh adalah pati umbi suweg.

\section{Proses Pembuatan Edible Film}

Pembuatan edible film diawali dengan menyiapkan aquades sebanyak $125 \mathrm{ml}$ kemudian penambahan pati sesuai perlakuan $(3 \%, 4 \%$, dan $5 \%)(\mathrm{b} / \mathrm{v})$, penambahan lilin lebah sesuai perlakuan $(1 \%, 2 \%$, dan $3 \%)(\mathrm{b} / \mathrm{v})$, penambahan gliserol 1,25\% dan STTP 0,4\%. Adonan edible film dipanaskan diatas hot plate stirrer hingga mencapai suhu \pm 85 o $\mathrm{C}$ dan dipertahankan selama 5 menit. Selama proses pemanasan tersebut adonan terus diaduk menggunakan magnetic stirrer.

Larutan edible film kemudian dilakukan proses pendinginan sampai suhu $35{ }^{\circ} \mathrm{C}-40{ }^{\circ} \mathrm{C}$. Adonan edible film selanjutnya dicetak pada loyang yang telah dilapisi plastik dan kaca. Cetakan dikeringkan menggunakan cabinet dryer dengan suhu \pm 50 o C selama 24 jam. Setelah dikeringkan edible film dilakukan penyimpanan selama 24 jam dan kemudian dilepaskan dari cetakan.

\section{Parameter Penelitian}

Penelitian ini bertujuan untuk karakteristik edible film pati umbi suweg (Amorphaphollus paeoniifolius) dengan variasi konsentrasi lilin lebah. Karakteristik yang dianalisis diantaranya adalah ketebalan edible film, elongasi, kuat tarik, laju transmisi uap air (water vapor transmission rate/ WVTR), kelarutan dalam air, transparansi dan struktur permukaan. 


\section{Rancangan Percobaan dan Analisa Data}

Penelitian ini menggunakan rancangan acak kelompok faktorial. Faktor pertama yaitu perbedaan konsentrasi pati umbi suweg S1 (3\%), S2 (4\%), dan S3 $(5 \%)(b / v)$, sedangkan faktor kedua yaitu perbedaan konsentrasi lilin lebah L1 (1\%), L2 (2\%), dan L3 (3\%) (b/v). Data yang diperoleh dianalisis dengan menggunakan Analysis of Variant (ANOVA) dan dan dilanjutkan uji banding DMRT (Duncan's Multiple Range Test) dengan taraf nyata 5\% $(\alpha=0,05)$.

\section{HASIL DAN PEMBAHASAN}

\section{Bahan Baku Pati Umbi Suweg}

Berdasarkan hasil pengukuran (Tabel 1) diketahui bahwa kadar air pati umbi suweg lebih tinggi dibandingkan hasil penelitian Richana dan Sunarti (2004) yaitu 9,4\%; penelitian Septiani,dkk. (2015) yaitu 6,57\%; dan penelitian Faridah (2005) yaitu 4,7\%. Nilai kadar air pati umbi suweg yang lebih tinggi dari penelitian lainnya ini masih memenuhi persyaratan standar mutu pati SNI 013751-2009 yang menyatakan bahwa nilai maksimum kadar air pati yaitu 14,5\%. Kadar air menjadi salah satu parameter penting dalam menentukan mutu pati yang mempengaruhi hasil akhir produk. Menurut Hafidz dan Rini (2017) menyatakan bahwa semakin tinggi kadar air yang terkandung pada pati dapat menyebabkan resiko kerusakan pada saat proses penyimpanan karena adanya mikroba yang berkembang. Kadar air yang tinggi pada pati dapat disebabkan pada proses pengeringan suhu yang digunakan kurang tinggi atau waktu yang digunakan kurang lama. Pengeringan pada pati bertujuan untuk mengurangi kadar air sampai batas tertentu sehingga pertumbuhan mikroba dan aktivitas enzim penyebab kerusakan pada pati dapat dihambat.

Tabel 1. Analisa Bahan Baku Pati Umbi Suweg

\begin{tabular}{lll}
\hline Analisa & Hasil & Literatur \\
\hline Kadar Air & $11,05 \%$ & Maks. $14,5 \% *$ \\
Kadar Pati & $75,05 \%$ & $76,61 \% * *$ \\
Kadar Amilosa & $37,80 \%$ & $37,02 \% * *$ \\
\hline
\end{tabular}

Sumber : * SNI 01-3751-2009 (2009) ** Cecep (2009)

Kadar pati yang dihasilkan dari analisa bahan baku umbi suweg adalah $75.05 \%$. Hasil ini tidak jauh berbeda dengan hasil literatur Kadar pati dari suatu bahan dipengaruhi oleh umur panen umbi. Hal ini sesuai dengan pernyataan Hafidz dkk. (2017) bahwa semakin tua umur umbi yang dipanen maka akan menghasilkan kadar pati yang rendah karena kadar pati yang telah optimum pada umbi akan dikonversi secara perlahan menjadi serat dan menurunkan kadar pati yang telah terkandung. Umbi suweg pada penelitian umur panenya 
tidak terlalu tua dikarenakan masih awal musim tumbuh umbi ini segera dipanen sehingga menghasilkan kadar pati yang cukup tinggi.

Pati mengandung fraksi linear dan bercabang dalam jumlah tertentu. Fraksi linearnya berupa amilosa, sedangkan sisanya amilopektin. Berdasarkan hasil analisa (tabel 1) kadar amilosa yang dihasilkan tidak jauh berbeda dengan hasil literatur. Variabilitas jumlah amilosa pada setiap bahan diakibatkan karena adanya kompleksitas biosintesis pati yang dipengaruhi oleh faktor genetik berbagai enzim dan kondisi lingkungan (Copeland et al. 2009). Kadar amilosa sangat berperan pada proses gelatinisasi, retrogadasi dan lebih menentukan karakteristik pasta pati. Menurut Richana dan Sunarti (2004) pati yang mengandung kadar amilosa yang semakin tinggi mempunyai ikatan hidrogen yang lebih besar karena jumlah rantai lurus yang besar dalam granula, sehingga membutuhkan energi yang lebih besar untuk gelatinisasi. Kadar amilosa yang semakin banyak menyebabkan teksturnya menjadi keras.

\section{Analisis Fisik dan Mekanik Edible Film}

Ketebalan merupakan salah satu parameter penting yang berpengaruh terhadap penggunaan edible film sebagai pengemas dan pelapis produk. Ketebalan edible film meningkat seiring bertambahnya penambahan konsentrasi lilin lebah. Hal ini sesuai dengan pernyataan Dhimas dkk. (2018) bahwa peningkatan konsentrasi lilin lebah dapat meningkatkan ketebalan edible film karena terbentuknya kristal lilin lebah pada matriks film. Menurut Kurniawati (2015) apabila lemak didinginkan, maka panas yang hilang akan memperlambat gerakan molekul dalam lemak, sehingga jarak antar molekul menjadi lebih kecil dan mengakibatkan gaya tarik menarik antar molekul ini timbul yang biasa disebut dengan gaya Van der Walls. Gaya Van der Walls menyebabkan asam lemak dalam molekul lemak akan tersusun secara secara sejajar dan saling bertumpuk serta berikatan membentuk kristal yang menyebabkan ketebalan meningkat seiring dengan pertambahan konsentrasi lilin lebah yang ditambahkan.

Nilai ketebalan yang tidak signifikan dimana penambahan lilin lebah yang semakin meningkat menunjukkan kenaikan kemudian mengalami penurunan. Hal ini disebabkan karena konsentrasi lilin lebah yang semakin tinggi maka akan melampui titik jenuhnya sehingga menyebabkan banyak lilin lebah yang tidak terlarut dan mengurangi jumlah volume sehingga berdampak pada ketebalan edible film yang semakin rendah nilainya. Hal ini sesuai dengan pernyataan Herawan (2015) bahwa komposisi cairan edible film yang ditambahkan lilin lebah melampui titik jenuhnya dapat menyisakan lilin lebah yang tidak larut sehingga ketika pada suhu ruang menjadi gumpalan dan 
mengurangi volume dalam larutan edible film yang berdampak pada ketebalan edible film yang semakin rendah. Jumlah larutan yang dituang juga mempengaruhi ketebalan edible film. Hal ini sesuai pernyataan Azizah (2018) bahwa ketebalan edible film dipengaruhi oleh volume larutan yang dituangkan kedalam cetakan. Edible film akan terlihat lebih tebal jika volume larutan yang dituangkan kedalam cetakan lebih banyak. Pada penelitian ini jumlah volume larutan aquades yang digunakan sebanyak $125 \mathrm{ml}$ sehingga edible film yang dihasilkan tidak terlalu tebal. Penambahan pati umbi suweg yang semakin tinggi juga meningkatkan ketebalan edible film. Hal ini sesuai dengan pernyataan Warkoyo,dkk. (2014) bahwa penambahan jumlah pati yang semakin besar, akan meningkatkan polimer penyusun matriks film dan total padatan edible film semakin besar sehingga film yang dihasilkan semakin tebal.

Tabel 2. Karakteristik Fisik dan Mekanik Edible Film Pati Umbi Suweg

\begin{tabular}{lllllll}
\hline Perlakuan & $\begin{array}{l}\text { Ketebalan } \\
(\mathrm{mm})\end{array}$ & $\begin{array}{l}\text { Transparansi } \\
\left(\mathrm{mm}^{-1)}\right.\end{array}$ & $\begin{array}{l}\text { Elongasi } \\
(\%)\end{array}$ & $\begin{array}{l}\text { Kuat } \\
\text { Tarik } \\
(\mathbf{M P a})\end{array}$ & $\begin{array}{l}\text { Kelarutan } \\
(\%)\end{array}$ & $\begin{array}{l}\text { WVTR } \\
\left(\mathrm{gram} / \mathbf{m}^{2} / 24\right. \\
\text { jam})\end{array}$ \\
\hline S1L1 $(3 \%: 1 \%)$ & $0,163^{\mathrm{a}}$ & $5,194^{\mathrm{b}}$ & $14,859^{\mathrm{f}}$ & $8,166^{\mathrm{b}}$ & $22,557^{\mathrm{a}}$ & $2,931^{\mathrm{a}}$ \\
S1L2 $(3 \%: 2 \%)$ & $0,158^{\mathrm{a}}$ & $5,633^{\mathrm{b}}$ & $9,377^{\mathrm{a}}$ & $4,457^{\mathrm{a}}$ & $49,252^{\mathrm{d}}$ & $3,014^{\mathrm{ab}}$ \\
S1L3 $(3 \%: 3 \%)$ & $0,157^{\mathrm{a}}$ & $4,235^{\mathrm{a}}$ & $13,141^{\mathrm{e}}$ & $6,439^{\mathrm{ab}}$ & $60,642^{\mathrm{f}}$ & $3,125^{\mathrm{ab}}$ \\
S2L1 $(4 \%: 1 \%)$ & $0,172^{\mathrm{ab}}$ & $5,332^{\mathrm{b}}$ & $12,203^{\mathrm{b}}$ & $12,666^{\mathrm{d}}$ & $62,433^{\mathrm{g}}$ & $3,208^{\mathrm{b}}$ \\
S2L2 $(4 \%: 2 \%)$ & $0,182^{\mathrm{b}}$ & $5,194^{\mathrm{b}}$ & $15,115^{\mathrm{g}}$ & $11,442^{\mathrm{c}}$ & $39,322^{\mathrm{ab}}$ & $3,389^{\mathrm{b}}$ \\
S2L3 (4\%:3\%) & $0,163^{\mathrm{a}}$ & $5,770^{\mathrm{b}}$ & $12,940^{\mathrm{c}}$ & $13,778^{\mathrm{e}}$ & $78,970^{\mathrm{h}}$ & $3,569^{\mathrm{c}}$ \\
S3L1 (5\%:1\%) & $0,193^{\mathrm{b}}$ & $5,308^{\mathrm{b}}$ & $16,597^{\mathrm{i}}$ & $25,677^{\mathrm{h}}$ & $56,142^{\mathrm{e}}$ & $3,667^{\mathrm{d}}$ \\
S3L2 (5\%:2\%) & $0,181^{\mathrm{b}}$ & $3,768^{\mathrm{a}}$ & $15,515^{\mathrm{h}}$ & $17,324^{\mathrm{f}}$ & $46,057^{\mathrm{c}}$ & $3,778^{\mathrm{e}}$ \\
S3L2 (5\%:3\%) & $0,190^{\mathrm{b}}$ & $4,388^{\mathrm{ab}}$ & $13,074^{\mathrm{d}}$ & $25,655^{\mathrm{g}}$ & $43,679^{\mathrm{b}}$ & $3,958^{\mathrm{f}}$
\end{tabular}

Angka-angka yang diikuti oleh huruf yang tidak sama menunjukkan perbedaan yang nyata menurut uji Duncan a 5\%

Transparansi merupakan kemampuan edible film untuk meneruskan cahaya. Transparansi edible film dipengaruhi oleh komponen penyusun dan ketebalan film. Semakin tinggi nilai ketebalan maka akan berbanding lurus dengan nilai transparansi yang dihasilkan dikarenakan banyaknya cahaya yang diserap oleh spektrofotometer melalui edible film. Lilin lebah yang digunakan dalam penelitian ini adalah lilin lebah yang bewarna kuning. Penambahan lilin lebah yang semakin tinggi menyebabkan penurunan nilai transparansinya. Hal 
ini sesuai dengan pernyataan Johan dan Zubaidah (2017) konsentrasi lilin lebah yang ditambahkan semakin tinggi akan meningkatkan kekentalan larutan film dengan adanya padatan yang terlarut semakin meningkat, sehingga menyebabkan polimer pembentuk film bertambah banyak akibat kekentalan film yang semakin meningkat. Menurut Golsbreg and Williams (2003) peningkatan viskositas dari suatu lilin lebah yang ditambahkan pada larutan edible film akan berpengaruh terhadap edible film karena tampak kusam dan buram menyebabkan pembauran cahaya meningkat sehingga tingkat transparansinya menurun. Nilai transparansi yang cenderung naik turun ini disebabkan oleh munculnya gelembung ketika edible film telah kering. Hal ini dapat disebabkan karena berbagai faktor salah satunya adalah pemanasan lilin lebah yang melebihi titik leburnya. Sesuai dengan pernyataan Sihombing (2002) bahwa lilin lebah yang telah mencair dan terus dipanaskan melebihi titik leburnya, maka akan ada uap yang juga naik ke permukaan dan jika mendidih akan menghasilkan gelembung uap.

Menurut Setiani dkk. (2013) transparansi dipengaruhi pula oleh karakteristik dari bahan pembuatannya dalam hal ini pati suweg yang digunakan memiliki warna yang tidak putih namun cenderung bewarna putih kecoklatan sehingga menyebabkan transparansi edible film meningkat atau tidak tembus pandang. Kandungan amilosa dari umbi suweg yang cukup tinggi juga menyebabkan transparansi menjadi menurun. Hal ini sesuai dengan pernyataan Krochta et al. (1994) bahwa kandungan amilosa yang tinggi dapat menyebabkan sifat transparansi yang rendah akibat terbentuknya matriks tiga dimensi yang terbentuk yang dapat mempengaruhi daya serap pati terhadap penambahan gliserol.

Elongasi merupakan persentase pemanjangan yang menggambarkan persen pertambahan panjang bahan materi edible film dari panjang awal pada saat mengalami penarikan hingga mengalami putus. Nilai elongasi menunjukkan suatu kemapuan edible film untuk memanjang hingga batasnya. Penambahan lilin lebah mengalami kenaikan pada konsentrasi $2 \%$ dan mengalami penurunan pada konsentrasi $3 \%$. Hal ini sesuai dengan pernyataan Herawan (2015) bahwa penurunan ini disebabkan karena komposisi cairan edible film yang ditambahkan lilin lebah melampui titik jenuhnya sehingga terdapat lilin lebah yang berlebih berada fase tersendiri diluar fase pati umbi suweg yang menyebabkan film semakin tidak homogen. Keadaan tersebut menyebabkan penurunan gaya intermolekul antar rantai menurun sehingga menyebabkan edible film cepat putus. Hal ini sesuai dengan pernyataan Handito (2011) bahwa semakin tinggi konsentrasi lilin lebah yang ditambahkan maka 
molekul lilin lebah akan membentuk matriks film yang semakin kuat sehingga menyebabkan film menjadi tidak elastis dan mudah putus.

Konsentrasi lilin lebah yang semakin besar menyebabkan struktur matrik polimer yang dihasilkan lebih rapat dan kuat. Hal ini sesuai dengan pernyataan Azizah (2018) bahwa lilin lebah meiliki fase kristalin dimana terjadi daya tarik antar asam lemak yang berdekatan dalam kristal sehingga menyebabkan jumlah matrik polimer meningkat dan membentuk film dengan struktur polimer yang rapat sehingga film yang dihasilkan kuat namun kemampuan merenggangnya semakin berkurang. Penambahan pati umbi suweg yang semakin meningkat tidak menghasilkan kenaikan nilai elongasi yang signifikan. Hal ini sesuai dengan pernyataan Warkoyo dkk. (2014) bahwa penambahan pati yang semakin meningkat mengakibatkan sifat plastis film semakin rendah dan persen pemanjangan semakin turun dikarenakan terjadinya berbagai modifikasi struktur dalam jaringan pati, matriks film berubah menjadi kurang rapat, rantai polimer bergerak dan fleksibilitas film meningkat. Menurut Rahim et al., (2010) persentase pemanjangan edible film dikatakan baik jika nilainya lebih dari 50\% dan dikatakan kurang baik jika nilainya kurang dari 10\% dikarenakan semakin kuat edible film yang terbentuk maka semakin sulit bagi suatu film untuk merenggang atau memanjang sehingga akan memperkecil persentase pemanjangan. Penelitian ini menghasilkan nilai elongasi lebih dari $10 \%$ artinya edible film yang dihasilkan sudah cukup baik.

Kuat tarik merupakan salah satu parameter penting bagi sebuah edible film sebagai pengemas dan pelapis produk. Kuat tarik diartikan sebagai gaya tarik maksimum yang dapat ditahan sebuah film hingga terputus. Menurut Japanese Industrial Standar (1975) minimal nilai kuat tarik pada edible film adalah 3,92 MPa. Hal ini edible film yang dihasilkan dalam penelitian ini telah memenuhi standar yang telah ditetapkan. Penambahan lilin lebah semakin tinggi pada edible film menyebabkan kekuatan tarik semakin tinggi dan setelah itu mengalami penurunan. Hal ini sesuai dengan pernyataan Dhewi (2011) bahwa lilin lebah mempunyai sifat menurunkan kekakuan supaya film lebih fleksibel sehingga kekuatan film semakin tinggi konsentrasi penambahan lilin lebah mengalami penurunan. Menurut Herawan (2015) konsentrasi lilin lebah yang semakin tinggi dapat menurunkan nilai kuat tarik suatu bahan karena lilin lebah merupakan lipid yang tidak larut dalam air sehingga pada saat pembuatan film tidak terbentuk ikatan dengan baik dan menurunkan nilai kuat tariknya. Selain itu, ikatan kohesi antar polimer akan semakin kecil yang mengakibatkan merenggangnya jarak antar molekul sehingga edible film menjadi lebih mudah putus. Peningkatan nilai kuat tarik seiring bertambahnya konsentrasi lilin lebah yang ditambahkan dapat disebabkan karena lilin lebah 
memiliki fase kristalin. Hal ini sesuai dengan pernyataan Azizah (2018) bahwa lilin lebah memiliki fase kristalin yang dapat menyebabkan terjadinya daya tarik antar asam lemak yang berdekakatan dalam kristal sehingga jumlah matrik polimer meningkat dan membentuk film dengan struktur polimer yang rapat dan menghasilkan edible film yang tidak mudah sobek.

Penambahan pati umbi suweg yang semakin banyak juga meningkatkan nilai kuat tarik edible film yang dihasilkan. Hal ini sesuai dengan pernyataan Warkoyo dkk. (2014) bahwa penambahan konsentrasi pati yang semakin banyak, matrik yang terbentuk semakin banyak sehingga matriks film yang dihasilkan menjadi semakin kokoh dan kekuatan yang diberikan untuk menyangga beban dari luar semakin bertambah besar. Nilai kuat tarik yang bertambah besar menunjukkan ketahanan terhadap kerusakan akibat peregangan dan tekanan menjadi semakin besar sehingga dapat mempertahankan kualitas fisik yang baik. Menurut Alvez dkk. (2007) konsentrasi pati yang ditambahkan pada edible film semakin banyak menyebabkan kadar amilosa dalam larutan edible film semakin meningkat pula. Hal ini menyebabkan jumlah polimer dalam formasi matriks semakin banyak sehingga ikatan antar polimer semakin kuat dan kuat tarik yang dihasilkan menjadi lebih besar.

Kelarutan merupakan suatu tolak ukur untuk edible film dapat larut ketika akan dikonsumsi dan juga untuk penentuan biodegradable film ketika akan dijadikan atau digunakan untuk pengemasan. Berdasarkan tabel diatas dapat dilihat bahwa formulasi pati umbi suweg dan lilin lebah tidak berpengaruh terhadap kelarutan edible film. Menurut Johan dan Zubaidah (2017) menyatakan bahwa semakin banyak lilin lebah yang ditambahkan dalam larutan edible film menyebakan meningkatnya matriks film sehingga film semakin kuat dan tidak mudah hancur karena air. Semakin tinggi konsentrasi lilin lebah yang ditambahkan, maka daya larut edible film dalam air akan semakin menurun dikarenakan lilin lebah merupakan suatu lipid yang bersifat hidrofobik dan tidak mudah larut dalam air jika dalam jumlah yang banyak. Menurut Santoso dkk. (2011) peningkatan molekul larutan menyebabkan matriks film semakin banyak, sehingga struktur film yang kuat dengan struktur jaringan film yang semakin kompak dan kokoh dapat meningkatkan kekuatan film sehingga tidak mudah hancur oleh air.

Penambahan pati umbi suweg yang semakin tinggi menghasilkan nilai kelarutan yang cenderung tidak signifikan namun pada penambahan pati umbi suweg konsentrasi 5\% nilainya lebih rendah daripada yang lain. Hal ini sesuai dengan pernyataan Warkoyo dkk. (2014) bahwa kelarutan edible film dalam air akan menurun dengan meningkatnya konsentrasi pati dikarenakan adanya 
gugus hidrofilik pada bahan penyusun yang mengalami penurunan. Semakin rendah gugus hidrofilik pada bahan penyusun tersebut dapat menyebabkan terjadinya penurunan kelarutan edible film.

Laju transmisi uap air merupakan salah satu sifat penting dari edible film, karena hal tersebut menunjukkan kemapuan film untuk menahan perpindahan uap air agar dapat digunakan untuk memperkirakan daya simpan produk yang dikemas dan dilapisi didalamnya. Edible film sebagai pengemas dan pelapis suatu produk diharapkan memiliki laju transmisi uap air yang kecil agar memperpanjang umur simpannya. Menurut Japanese Industrial Standard edible film sebagai pengemas yang baik memiliki maksimal nilai WVTR sebesar 7 gram $/ \mathrm{m} 2 / 24$ jam. Hasil WVTR menurut penelitian ini telah sesuai dengan standar yang telah ditetapkan. Laju transmisi uap air akan semakin menurun seiring dengan peningkatan konsentrasi lilin lebah yang ditambahkan kedalam edible film. Hal ini sesuai dengan pernyataan Johan dan Zubaidah (2017) bahwa semakin meningkatnya konsentrasi lilin lebah yang ditambahkan maka akan menurunkan laju transmisi uap air dikarenakan meningkatnya molekul larutan menyebabkan matriks film semakin banyak, sehingga struktur film menjadi kuat, kompak dan kokoh. Selain itu lilin lebah memiliki polaritas yang rendah dan struktur kristal yang padat. Menurut Arsi dkk. (2013) penambahan lilin lebah yang semakin banyak dapat menurunkan laju transmisi uap air karena lilin lebah bersifat hidrofobik yang kuat sehingga pada saat proses pengeringan edible film, lilin lebah membentuk jaringan kristal yang berbentuk orthorombik sehingga dapat berfungsi sebagai barier terhadap uap air.

Berdasarkan penelitian tersebut semakin tinggi konsentrasi lilin lebah laju transmisi uap air yang dihasilkan semakin tinggi. Hal ini sesuai dengan literatur dikarenakan ketebalan edible film yang dihasilkan semakin tinggi nilainya seiring bertambahnya konsentrasi lilin lebah yang ditambahkan. Menurut Azizah (2018) nilai ketebalan akan mempengaruhi nilai laju transmisi uap air dan nilai permeabilitas edible film terhadap uap air dikarenakan nilainya berbanding terbalik. Ketebalan film digambarkan dengan jarak yang harus ditempuh oleh uap air untuk berdifusi melewati film. Senakin tebal edible film tersebut maka jarak tempuh uap air yang berdifusi melewati film akan semakin jauh dikarenakan uap air memerlukan waktu tertentu untuk melewati film. Jika edible film tersebut semakin tebal, maka waktu yang diperlukan untuk berdifusi semakin lama.

Laju transmisi uap air edible film akan semakin tinggi seiring dengan bertambahnya konsentrasi pati. Berdasarkan data diatas, konsentrasi pati umbi suweg yang ditambahkan semakin tinggi menghasilkan nilai laju transmisi uap air yang semakin tinggi pula. Hal ini sesuai dengan pernyataan Warkoyo dkk. 
(2014) bahwa pati tergolong dalam senyawa hidrokoloid yang bersifat hidrofilik sehingga kurang dapat menahan transmisi uap air. Edible film tersebut meskipun kurang dapat menahan transmisi uap air namun dapat mengatur migrasi penguapan air dan merupakan barrier yang baik terhadap oksigen, karbondioksida dan lipid. Pati umbi suweg mengandung amilosa yang cukup besar sehingga peningkatan pati akan diikuti dengan peningkatan amilosa yang menyebabkan jumlah kelompok hidroksil bebas semakin banyak dan mengakibatkan laju transmisi uap air semakin tinggi. Hal ini sesuai dengan pernyataan Alves dkk. (2007) bahwa nilai permeabilitas uap air film akan meningkat dengan penambahan amilosa yang semakin banyak dikarenakan jumlah kelompok hidroksil bebas menjadi lebih tinggi sehingga dapat meningkatkan interaksinya dengan air, dan transmisi uap air melalui film. Lilin lebah yang ditambahkan semakin meningkat menyebabkan pori-pori semakin membesar dikarenakan pembentukan saluran yang tidak tampak sehingga laju transmisi uap air semakin besar. Sebaliknya lilin lebah yang ditambahkan semakin menurun menyebabkan pori-porinya lebih kecil sehingga dapat menghambat laju transmisi uap air yang terjadi pada edible film (Rawdkuen et al. 2008).

\section{Struktur Permukaan Edible Film}

A)
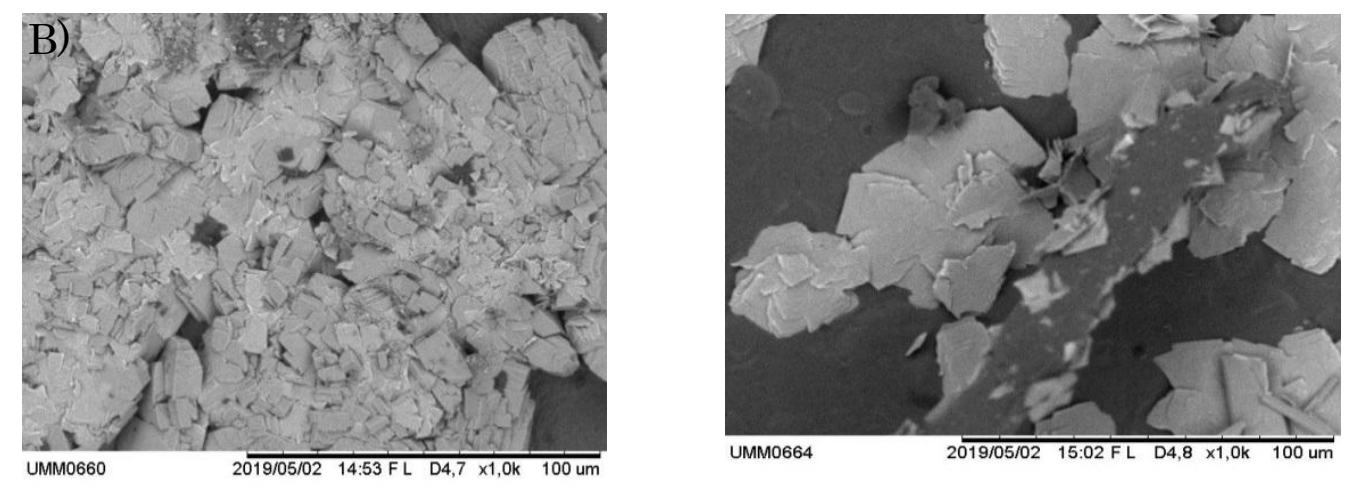

C)

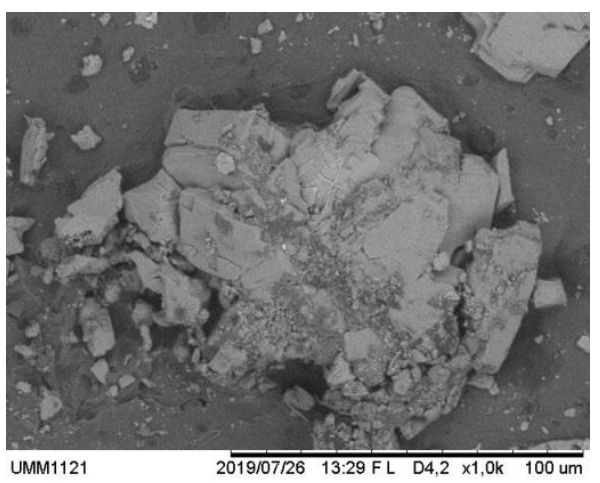

D)



Gambar 1. Perbandingan permukaan Edible Film konsentrasi terendah dan tertinggi dengan Perbesaran 1000 kali (A) Pati Umbi Suweg 3\% (b/v) dan Lilin Lebah 1\% (b/v) (B) Pati Umbi Suweg 5\% (b/v) dan Lilin Lebah 3\% (b/v) (C) Pati 
Umbi Suweg $3 \%(\mathrm{~b} / \mathrm{v})$ dan Lilin Lebah 3\% (b/v) (D) Pati Umbi Suweg 5\% (b/v) dan Lilin Lebah $1 \%(\mathrm{~b} / \mathrm{v})$

Struktur permukaan edible film yang diuji adalah pati umbi suweg konsentrasi terendah dan tertinggi yang dianalisa menggunakan Scanning Electron Microscopy (SEM) dengan perbesaran 1000 kali. Gambar A menunjukkan edible film dengan konsentrasi pati umbi suweg dan lilin lebah dengan konsentrasi paling rendah terlihat bahwa pori-porinya lebih kecil. Gambar B menunjukkan edible film dengan konsentrasi pati umbi suweg dan lilin lebah dengan konstrasi paling tinggi terlihat bahwa pori-porinya lebih besar. Ukuran pori ini menunjukkan kenaikan seiring dengan penambahan komposisi lilin sarang lebah. Hal ini sesuai dengan pernyataan Dian (2014) bahwa semakin banyak komposisi lilin yang diberikan maka pori yang terbentuk semakin besar dan merata dikarenakan pada saat proses pembuatan edible film melalui pemanasan dan pengadukan yang membuat lilin lebah menjadi bingkai atau pori film.

Penampakan permukaan film dengan konsentrasi pati tinggi terlihat lebih rata dan lembut sedangkan film dengan konsentrasi pati rendah terlihat lebih kasar. Hal ini disebabkan karena penambahan pati yang semakin besar menyebabkan peluang untuk terbentuknya celah-celah kecil pada permukaan film semakin kecil sehingga permukaan film menjadi lebih rata dan halus. Hal ini sesuai dengan pernyataan Warkoyo dkk. (2014) bahwa penambahan pati yang semakin besar menghasilkan permukaan film yang lebih halus dikarenakan pori-pori atau lubang yang berhubungan dengan pembentukan saluran tidak tampak pada film. Menurut Rawdkuen et al. (2008) film yang kompak struktur permukaannya alan menghasilkan laju uap air yang rendah dikarenakan dapat menahan transmisi uap air dari film. Konsentrasi lilin lebah yang semakin tinggi menghasilkan pori-pori yang lebih besar dan berpengaruh terhadap nilai laju transmisi uap air semakin besar. Hal ini sesuai dengan hasil penelitian bahwa semakin tinggi lilin lebah yang ditambahkan, menyebabkan pori-pori menjadi lebih besar dan laju transmisi uap air semakin besar dikarenakan kurang terhambatnya kehilangan uap air oleh lapisan edible film disebabkan oleh pori-pori yang terlalu besar. Pori yang besar menyebabkan penyerapan uap air yang terjadi disebabkan karena adanya proses difusi aktif yang melibatkan pelarutan uap air pada edible film, kemudian berdifusi melalui edible film dan dilepaskan pada sisi yang lain (Dhimas dkk., 2018).

\section{KESIMPULAN}

Kesimpulan dari penelitian ini adalah terjadinya interaksi antara penambahan variasi pati umbi suweg dan lilin lebah terhadap ketebalan, transparansi, kuat tarik, elongasi, kelarutan dan laju transmisi uap air edible 
film. Struktur permukaan yang dihasilkan dengan kandungan pati umbi suweg $3 \%(\mathrm{~b} / \mathrm{v})$ menhasilkan permukaan edible film yang rata dan halus, sedangkan penambahan lilin lebah $1 \%(\mathrm{~b} / \mathrm{v})$ menghasilkan pori-pori yang kecil. Perlakuan terbaik yang sesuai dengan standar berdasarkan uji de garmo adalah edible film pada perlakuan S3L1 ketebalan sebesar 0,193 mm; transparansi sebesar 5,3077 mm-1; elongasi sebesar 16,597\%; kuat tarik sebesar 25,6770 Mpa; kelarutan sebesar 56,142\% dan laju transmisi uap air sebesar 3,667 gram/m2/24 jam

\section{REFERENSI}

Alvez, V.D., Mali, S., Beleia, A. Dan Grossman, M.V.E. 2007. Effect of Glycerol and Amylase Enrichment on Cassava Starch Film Properties. Journal Of Food Engineering. 78: 941-946

Arsi, D.D., YS Darmanto, dan Laras R. 2013. Karakteristik Edible Film Komposit Semirefined Karaginan dari Rumput Laut Eucheuma Cottonii dan Beeswax. Jurnal Pengolahan dan Bioteknologi Hasil Perikanan. 2 (3) : 1-10

Azizah, R.M. 2018. Karakteristik Edible Film Komposit Dari Pati Sagu, Gelatin, dan Lilin Lebah (Beeswax). Jurnal TABARO. 2 (2), Desember 2018

Copeland I, Blazek J, Salman H, dan Tang MC. 2009. Form and Functionally of Starch.Food Hydrocolid.23: 1527-1534.

Dhewi, L. S. 2011 Pengaruh Penambahan Plasticizer Lilin Lebah Terhadap Karakteristik Edible Film Pati-Kitosan. Skripsi. Surabaya: Fakultas Sains dan Teknologi Universitas Airlangga.

Dhimas, S., Rahayu K., dan Agustono. 2018. Pengaruh Penambahan Beeswax Sebagai Plasticizer Terhadap Karakteristik Fisik Edible Film Kitosan. Jurnal Ilmiah Perikanan dan Kelautan. 10 (1) April 2018

Dian, N.K. 2014. Sintesis dan Karakterisasi Hidroksiapatit dari Cangkang Keong Sawah (Pila ampullacea) dengan Porogen Lilin Sarang Lebah Sebagai Aplikasi Scaffold. Skripsi. Departemen Fisika. Fakultas Sains dan Teknologi. Universitas Airlangga.

Goldbreg,D. and Williams. 2003. A User's to the General Health Questionnaire. Windsor. .UK: NEFR Nelson. Published online 2003.

Hafidz, U., Fafa N., Bambang S., Rini U., dan Rizky M. 2017. Sifat Fisik dan Kimia Tepung Umbi Suweg (Amophophallus campamulatus BI) di Jawa Tengah. Program Studi Pangan, Fakultas Teknik, Universitas PGRI Semarang.

Handito, D. 2011. Pengaruh Konsentrasi Karagenan Terhadap Sifat Fisik dan Mekanik Edible Film. Fakultas Pertanian. Universitas Mataram. Agroteksos. $21: 2-3$

Herawan, C. D. 2015. Sintesis dan Karakteristik Edible Film dari Pati Kulit Pisang dengan Penambahan Lilin Lebah (Beeswax). Skripsi. Semarang: Fakultas Matematika dan Ilmu Pengetauan Alam Universitas Negeri Semarang

JIS (Japanesse Industrial Standard) 2 1707. 1975. Japanese Standards Association 
Johan, A. dan Zubaidah E. 2017. Pengaruh Jenis Dan Konsentrasi Plasticizer Terhadap Sifat Fisik Edible Film Kolang-Kaling (Arenga pinnata). Jurnal Pangan dan Agroindustri. 5 (1) :13-25. Januari 2017

Krochta, Baldwin, Dan Nisperos-Carriedo. 1994. Edible Coatings and Films to Improve Food Quality. Technomic Publishing Company, Inc. Pennsylvania, (2), 215-218

Kurniawati, K 2015. Potensi Pemanfaatan Pati Propagul Bruguiera gymnorrhizza dalam Pembuatan dan Karakterisasi Edible Film dengan Konsentrasi Variasi Konsentrasi Sorbitol Sebagai Pemlastis. Skripsi. Surabaya: Fakultas Perikanan Universitas Airlangga

Rahim, A., N Alam., Haryadi dan Santoso, U. 2010. Pengaruh Konsentrasi Pati Aren dan Minyak sawit Terhadap Sifat Fisik dan Mekanik Edible Film. Fakultas Teknologi Pertanian UGM. Yogyakarta. J. Agroland 17(1) : 38-46.

Rawdkuen, S., S. Sai-Ut., A. Jongjareonrak and S. Benjakul. 2008. Properties of Edible Film Form Giant Cat Fish and Bovine Bone Gelatin : a Compared Study. 34th Congress on Science and Technology of Thailand. October 31st to November 2nd.

Richana N, dan Sunarti T.C. 2004. Karakterisasi Sifat Fisikokimia Tepung Umbi dan Tepung Pati dari Umbi Ganyong, Suweg, Ubi Kelapa dan Gembili. Jurnal Pasca Panen. 1(1): 29-37.

Santoso, B., F. Pratama, B. Hamzah, dan R. Pambayun. 2011. Pengembangan Edible Film Dengan Menggunakan Pati Ganyong Termodifikasi Ikatan Silang. Jurnal Teknologi dan Industri Pangan, 22(2):105-109.

Saputra, A., Musthofa L., dan Eng M. 2015. Studi Pembuatan dan Karakteristik Sifat Mekanik Plastik Biodegradable Berbahan Dasar Ubi Suweg (Amorphophallus campanulatus). Jurnal Keteknikan Pertanian Tropis dan Biosistem. 3(1) 1-6.

Septiani, D., Y. Hendrawan dan R. Yulianingsih. 2005. Uji Karakteristik Fisik, Kimia dan Organoleptik Pembuatan Tepung Umbi Suweg (Amorphophallus campanulatus B) Sebagai Bahan Pangan Alternatif. Jurnal Bioproses Komoditas Tropis 3(1) : 11-18

Setiani, W., T. Sudiarti dan L.Rahmidar. 2013. Preparasi dan Karakterisasi Edible Film dari Poliblend PatiSukun-Kitosan. Jurnal Kimia Valensi. 3(2): 100-109

Sihombing,D.T.H. 2002. Ilmu Ternak Lebah Madu. UGM Press.Yogyakarta.

Standar Nasional Indonesia (SNI). 2009. Tepung Terigu Sebagai Bahan Makanan (SNI 3751:2009). Jakarta : Badan Standarisasi Nasional

Warkoyo, Rahardjo, B., Marseno, Dj. W., dan Karyadi, J.N.W. 2014. Sifat fisik, Mekanik dan Barrier Edible Film Berbasis Pati Umbi Kimpul (Xanthosoma sagittifolium) yang Diinkorporasi dengan Kalium Sorbat. Jurnal Agritech. 34 (1): $72-81$ 